\title{
Toxicon
}

July 2012, Volume 60, Issue 1 , Pages $40-43$

http://dx.doi.org/10.1016/j.toxicon.2012.03.003

(c) 2012 Elsevier Ltd. All rights reserved.

\section{Influence of Crassostrea gigas (Thunberg) sexual maturation stage and ploidy on uptake of paralytic phycotoxins}

\author{
Marielle Guéguen ${ }^{a}$, Régis Baron ${ }^{b}$, Michèle Bardouil ${ }^{c}$, Hansy Haberkorn ${ }^{d}$, Philippe Soudant ${ }^{d}$, \\ Philippe Truquet ${ }^{c}$, Patrick Lassus ${ }^{c, *}$
}

\author{
a Microbiologie d'Intérêt Laitier et Alimentaire EA 3214, Université de Caen, Esplanade de la Paix, BP 5183, \\ 14032 Caen, France \\ b Ifremer, Laboratoire Science et Technologie de la Biomasse Marine, Rue de l'lle d'Yeu, BP 21105, 44311 \\ Nantes cedex, France \\ ${ }^{c}$ Ifremer, Laboratoire Phycotoxines, Rue de l'lle d'Yeu, BP 21105, 44311 Nantes cedex, France \\ d Laboratoire des Sciences de l'Environnement Marin, Institut Universitaire Européen de la Mer, Université de \\ Bretagne Occidentale, Place Copernic, Technopôle Brest-Iroise, 29280 Plouzané, France \\ *: Corresponding author : Patrick Lassus, email address : Patrick.lassus@ifremer.fr
}

\begin{abstract}
:
The purpose of this study was to assess paralytic phycotoxin uptake in diploid and triploid oysters at two stages of their sexual cycle corresponding to their status in early summer (June) and winter (November). Samples of diploid and triploid oysters were exposed to a toxic culture of Alexandrium minutum for 4 days in each season. No significant differences in filtration or clearance rates were observed during either November or June experiments. When diploid oysters were at resting stage (November), toxin uptake showed no significant difference between the ploidy classes. In contrast, when the diploid oysters were at the peak of their sexual maturation (June), the triploid oysters were seen to accumulate almost double the amount of paralytic toxins as the diploid ones.
\end{abstract}

Keywords: Paralytic shellfish poisoning ; Crassostrea gigas ; Diploid ; Triploid ; Contamination 


\section{$\underline{\text { Report }}$}

Since the 1970s, there has been a worldwide increase in the number of toxic events linked to phycotoxins (Hallegraeff 1995, Bricelj \& Shumway 1998a, 1998b). To date, based on their effects upon human health, about twelve different families of toxic compounds synthesised by marine microalgae have been discovered. The most hazardous phycotoxins found along French coasts are paralytic shellfish toxins (PSTs). These were detected in France for the first time in 1988 (Nezan and Ledoux, 1989; Lassus et al, 1994), in the "Abers" area of northern Brittany, where the causal micro-alga was soon identified as Alexandrium minutum. Other French areas were also later found to be contaminated by toxigenic Alexandrium spp. (Masselin et al. 2000, Sechet et al. 2003).

Phycotoxins are usually transferred from phytoplankton to man by marine vectors, such as bivalve molluscs, herbivorous or carnivorous crustaceans, or fish.

Data from French National Committee of Shellfish Farming (CNC) illustrate that shellfish farming is a common and important industry in Europe. Spain is in top position, producing about 270,000 tonnes of shellfish per year, followed by France with 200,000 tonnes produced per year. For oyster farming, however, France is the largest European producer with an annual average output of 128,500 tonnes (Crassostrea gigas). Nowadays, as far as French shellfish farming is concerned, triploid oyster production represents a significant proportion of the market. According to different estimations, triploids make up 30 to $50 \%$ of the total oyster production in France. Triploid oysters are attractive to producers for two main reasons: firstly, in contrast to their diploid counterparts, the inhibition of reproduction in triploid oysters means they can be sold throughout the year; secondly, some past studies showed them to have lower summer mortality than diploids due to a reduced energy expenditure (Kesarcodi-Watson et al. 2001, Garnier-Géré et al. 2002), a limited protein metabolism (Hawkins and Day 1996) and a more efficient immune system (Nell 2002, Duchemin et al. 2007). These last two characteristics provide them with an increased resistance under stress conditions, particularly towards pathogens and contaminants. 
Furthermore, the ANSES (the French Agency for Food, Environmental and Occupational Health \& Safety), in a memo published in 2001 (N: 2001-SA-0080), recommended the implementation of a research programme to investigate and compare bioaccumulation and detoxification in triploid and diploid oysters when exposed to either heavy metals, bacteria or phycotoxins. At that time no data were available on phycotoxins and, therefore, it appeared interesting to compare paralytic toxin bioaccumulation yields in diploid versus triploid oysters.

Although no specific research has been done on the impact of reproductive period on PST uptake and accumulation in oyster soft tissues, recent studies (Haberkorn et al. 2010b) have reported differences in overall bioaccumulation between reproductively mature diploid and triploid oysters (which have inhibited gametogenesis). However, these authors did not consider daily bioaccumulation rates, toxin profile changes or filtration rates.

So, given the lack of detailed published research on the impact of reproductive stage, it was important to compare the role of filtration rates, ploidy and toxin profiles on toxin 
uptake when oysters were exposed to PST-producing algae either during their reproductive

In a laboratory experiment, we took diploid and triploid oysters that were initially free from all contamination and whose ploidy had been individually confirmed by flow cytometry, and exposed sets of them to toxic algal cells at two stages of the diploid sexual cycle: in early winter (resting phase) and in early summer (maximum sexual maturity). The toxic dinoflagellate strain used for this contamination was Alexandrium minutum (AM89BM), which was grown in $\mathrm{L} 1$ medium at $16 \pm 1^{\circ} \mathrm{C}$, with $50 \pm 4 \mu$ mol photons $\mathrm{m}^{-2} \mathrm{~s}^{-1}$ illuminance and a 12/12 hour photoperiod. In November, twenty adult-sized oysters were placed in individual $850 \mathrm{~mL}$ trays (Lassus et al. 2007) at $16.0 \pm 0.4^{\circ} \mathrm{C}$, with a continuous supply of seawater (pumping rate: $150 \mathrm{ml} \mathrm{mn}^{-1}$ ). The $A$. minutum concentration of this recirculated seawater was continuously adjusted to $290 \pm 80$ cells $\mathrm{mL}^{-1}$ and, as the mean toxicity of this alga was 1.15 $\pm 0.07 \mathrm{pg}$ equiv. STX cell ${ }^{-1}$, this corresponded to a calculated toxic intake of $333.5 \pm 110.4 \mathrm{pg}$ $\mathrm{mL}^{-1}$. In June, mean cellular toxicity was lower, i.e $0.38 \pm 0.06 \mathrm{pg}$ equiv. STX cell ${ }^{-1}$ and therefore contamination of oysters was carried out with a higher continuous supply of $520 \pm$ 140 cells $\mathrm{mL}^{-1}$ A. minutum corresponding to a toxic intake equal to $206 \pm 84.4 \mathrm{pg} \mathrm{mL}^{-1}$. The contamination was continued over 4 days, during which biodeposits (faeces and pseudofaeces) were collected every day, making it possible to calculate filtration and clearance rates and thus compare oyster feeding behaviour using Hawkins et al. (1996) formulae. Finally, toxin content in oysters was quantified by HPLC-FLD using the method of Oshima (1995), as slightly modified by Masselin et al (2001) and toxicity was calculated from Oshima"s conversion factors. Gonyautoxins GTX1, GTX2, GTX3, GTX4, dc-GTX3 and dcGTX2, were directly separated whereas C1 and C2 toxins were detected indirectly and quantified following acidic hydrolysis of samples.

Toxicities expressed as $\mu \mathrm{g}$ STX eq. $100 \mathrm{~g}^{-1}$ shellfish flesh, and relative amounts of STX analogues were compared between diploid and triploid oysters within each experiment. No significant difference was observed between toxin contents of diploids and triploids at the 
resting stage (ANOVA, $p>0.05$; Fig. 1A). In contrast, when contamination was performed

when diploid oysters were at the peak of sexual maturation, the triploid oysters were significantly more contaminated than their diploid counterparts on days 2 (ANOVA, $p<0.05$ ), 3 (ANOVA, $p<0.05$ ) and 4 (ANOVA, $p<0.01$; Fig. 1B). For clearance (Fig. 2A and 2B) and filtration (Fig. 2C and 2D) rates, and toxin profiles, diploid and triploid oysters showed no significant differences whatever the reproductive stage considered (Fig. 2E shows the example of the peak of sexual maturation)

The significant differences in toxin uptake detected during the June experiment (Fig.1B) could be explained by the difference in the physiological state of the diploid oysters compared with the November experiment. In June, triploid oysters have a more active metabolism (especially oxidative metabolism) than diploid ones (Soletcknik et al. 1996), which are in late gametogenesis. Alternatively, dissimilarity in sensitivity or tolerance to PSTs could also explain the discrepancies observed in the amounts of PSTs accumulated by diploid and triploid oysters exposed to A. minutum. In a similar way, Haberkorn (2009) and Haberkorn et al. (2010b) found about twice the amount of toxins in triploid oysters as in diploid oysters in April, May and June (experiments repeated four times). In these studies, on the basis of different physiological parameters (gonad maturation state, phospholipid levels and amylase activity in the digestive gland, plasma and haemocytes specific parameters), the authors hypothesised that the difference in toxicity observed is the result of a difference in feeding or metabolic activity (Haberkorn 2009, Haberkorn et al. 2010b). Our observations did not reveal any differences in the filtration or clearance rates. The dissimilarity in toxicity could be due to a difference either in the assimilation rate or metabolism. However, no difference was observed in November. It is also important to note that metabolic and feeding responses in the Pacific oyster Crassostrea gigas vary according to sexual maturation stages (Soletchnik et al. 1996), although, in our case, no significant difference in clearance rate was observed in relation to sexual stage. However, according to Soletchnik et al. (1996), the oyster energy balance at the end of maturation is negative $\left(-15 \mathrm{~J} \mathrm{~h}^{-1}\right)$ while it remains between 110 and $170 \mathrm{~J} \mathrm{~h}^{-1}$ at the immature stage or for post-spawning oysters. This energy 
deficit observed at the end of sexual maturation could be due to a decrease in the absorption function. Diploid oysters would thus have a weaker absorption rate than triploid oysters at the end of sexual maturation. In a similar way, Berthollet-Marolle (2007) observed a better absorption rate in triploid oysters after April. Moreover, the lower mortality of triploid oysters can be explained by their low energy expenditure (notably for respiration and excretion) compared with diploid oysters, which confers an increased resistance to stress conditions (Kesarcodi-Watson et al. 2001b; Garnier-Géré et al. 2002). This low energy expenditure is due to a limited metabolism of proteins (Hawkins and Day, 1996). We can thus hypothesise that the contamination of diploid oysters is less than that of triploid oysters as a result of a change in the metabolism of diploid oysters at the sexual maturation stage.

It would be interesting to carry out further investigations on the influence of ploidy on detoxification, as recommended by ANSES. Furthermore, the present study has suggested that there is a possible effect of the reproductive status on PST uptake in diploid oysters. It would thus be worth testing the influence of oyster physiological status on toxin accumulation by repeating the experiments of the present study, under the same conditions, but at several more stages of reproduction.

\section{Acknowledgments}

The authors wish to express their thanks to the ANR National Programme "SEST" and to the SMIDAP (Région des Pays de Loire) Regional Organization for their financial support. They also would like to thank Dr Abdela Benabdelmouna (IFREMER, La Tremblade Experimental Station, France) for providing them with the diploid and triploid oysters. 


\section{References}

Berthollet-Marolle 2007. Amélioration du modèle individuel de croissance et de reproduction de type "Dynamic Energy Budget" chez l'huître creuse (Crassostrea gigas) et application aux cas particuliers des huîtres triploïdes. Mémoire de Master 2 « Sciences de la mer et du littoral », UBO,Plouzané.

Bricelj, V.M., Shumway, S.E., 1998a. An overview of the occurrence and transfer kinetics of paralytic shellfish toxins in Bivalve molluscs. In: Reguera, B., Blanco, J., Fernandez, M.L., Wyatt, T., (eds.) Harmful Algae, pp 431-436.

Bricelj, V.M., Shumway, S.E., 1998b. Paralytic shellfish toxins in bivalve molluscs: occurrence, transfer kinetics and biotransformation. Fisheries Sci. 6, 315-383.

Duchemin, M.B., Fournier, M., Auffret, M., 2007. Seasonal variations of immune parameters in diploid and triploid Pacific oysters, Crassostrea gigas (Thuenberg). Aquaculture 264, 73-81.

Garnier-Géré, P.H., Naciri-Graven, Y., Bougrier, S., Magoulas, A., Héral, M., Kotoulas, G., Hawkins, A., Gérard, A., 2002. Influence of triploidy, parentage and genetic diversity on growth of the Pacific oyster Crassostrea gigas reared in contrasting natural environments. Mol. Ecol. 11, 1499-1514.

Guéguen, M., Bardouil, M., Baron, R., Lassus, P., Truquet, P., Massardier, J., Amzil, Z., 2008. Detoxification of Pacific oyster Crassostrea gigas fed on diets of Skeletonema costatum with and without silt, following PSP contamination by Alexandrium minutum. Aquat. Living Resour. 2, 13-20.

Haberkorn H, 2009. Impact du dinoflagellé toxique Alexandrium minutum, sur l"huître creuse, Crassostrea gigas: approche intégrative. $\mathrm{PhD}$ thesis, Université de Bretagne Occidentale, France, 194 pp.

Haberkorn, H., Lambert, C., Le Goïc, N., Moal, J., Suquet, M., Guéguen, M., Sunila I., Soudant, P., 2010a. Effects of Alexandrium minutum exposure on nutrition-related processes and reproductive output in oysters Crassostrea gigas. Harmful Algae 9, 427-439.

Haberkorn, H., Lambert, C., Le Goïc, N., Guéguen, M., Moal, J., Palacios, E., Lassus, P., Soudant, P., 2010b. Effects of Alexandrium minutum exposure upon physiological and haematological variables of diploid and triploid of the oyster, Crassostrea gigas. Aquat. Toxicol. 97, 96-108.

Haberkorn, H., Tran D., Massabuau J.C., Ciret P., Savar V., Soudant P., 2011. Relationship between valve activity, microalgae concentration in the water and toxin accumulation in the digestive gland of the Pacific oyster, Crassostrea gigas, exposed to Alexandrium minutum. Marine Pollution Bulletin 62, 1191-119

Hallegraeff, G.M., 1995. 1. Harmful algal blooms: a global overview. In: Hallegraeff, G.M., (ed.) Manual on Harmful Marine Microalgae. IOC Manuals and Guides $N^{\circ} 33$ UNESCO, pp 1-22.

Hawkins, A.J.S., Day, A.J., 1996. The metabolic basis of genetic differences in growth efficiency among marine animals. J. Exp. Mar. Biol. Ecol. 203, 93-115. 
Hawkins, A.J.S., Smith, R.F.M., Bayne, B.L., Héral, M., 1996. Novel observations underlying the fast growth of suspension-feeding shellfish in turbid environments: Mytilus edulis. Mar. Ecol. Prog. Ser. 131, 179-190.

Kesarcodi-Watson, A., Klumpp, D.W., Lucas, J.S., 2001. Comparative feeding and physiological energetics in diploid and triploid Sydney rock oysters (Saccostrea commercialis) - II. Influences of food concentration and tissue energy distribution. Aquaculture 203, 195-216.

Lassus, P., Amzil, Z., Baron, R., Sechet, V., Barille, L., Abadie, E., Bardouil, M., Sibat, M., Truquet, P., Berard, J.B., Gueguen, M., 2007. Modelling the accumulation of PSP toxins in Thau Lagoon oysters (Crassostrea gigas) from trials using mixed cultures of Alexandrium catenella and Thalassiosira weissflogii. Aquat. Living Resour. 20, 59-67.

Lassus, P., Bardouil, M., Baron, R., Berard, J.B., Masselin, P., Truquet, P., Pitrat, J.P., 2005. Improving detoxification efficiency of PSP contaminated oysters (Crassostrea gigas Thunberg). Aquaculture Europe 3-6.

Lassus, P., Bardouil, M., Beliaeff, B., Masselin, P., Naviner, M., Truquet, P., 1999. Effect of a continous supply of the toxic dinoflagellate Alexandrium minutum Halim on the feeding behavior of the Pacific oyster (Crassostrea gigas Thunberg). J. Shellfish Res. 18, 211-216.

Lassus, P., Baron, R., Garen, P., Truquet, P., Masselin, P., Bardouil, M., Leguay, D., Amzil, Z., 2004. Paralytic shellfish poison outbreaks in the Penze estuary : Environmental factors affecting toxin uptake in the oyster, Crassostrea gigas. Aquat. Living Resour. $17,207-214$.

Lassus P, Ledoux M, Bardouil M, Bohec M, Erard E, 1994. Kinetics of Alexandrium minutum Halim accumulation in mussels and clams. Natural Toxins, 2, 329-333.

Masselin, P., Amzil, Z., Abadie, E., Nézan, E., Le Bec, C., Chiantella, C., Truquet, P., 2000. Paralytic shellfish poisoning on the French Mediterranean coast in autumn 1988: Alexandrium tamarense complex (Dinophyceae) as causative agent. In: Hallegraeff, G.M., Blackburn, S.I., Bolch, C.J., Lewis, R.J. (Eds.) Harmful Algae Blooms. JOCUNESCO, pp 407-410.

Nell, .J.A., 2002. Farming triploid oysters. Aquaculture 210, 69-88.

Nielsen, M.V., Stromgren, T., 1991. Shell growth response of mussels (Mytilus edulis) exposed to toxic microalgar. Mar. Biol. 108, 263-267.

Nezan E, Ledoux M, 1989. Red tide by Alexandrium minutum in France. Red Tide Newsletter, Sherkin Island Marine Station 2 (1), 2-3.

Oshima, Y., 1995. Chemical and enzymatic transformation of paralytic shellfish toxins in marine organisms. In: Lassus, P., Arzul, G., Erard-Le Denn, E., Gentien, P., Marcaillou-Le Baut, C., Lavoisier Publishing ILP (ed.) Harmful Marine Algal Blooms.

Sechet, V., Berard, J.B., Bohec, M., Bougaran, G., Carré, C., Masselin, P., Truquet, P. (2003) Growth and toxicity of Alexandrium catenella isolated from Thau lagoon (France) cultured in stirred tank bioreactors. In: Villarba, A., Reguera, B., Romalde, J.L., Bairas, R. (eds.) Molluscan Shellfish Safety, pp 135-144. 
Soletchnik, P., Goulletquer, P., Heral, M., Razet, D., Geairon, P., 1996. Evaluation of the energetic budget of rite Japanese oyster, Crassostrea gigas, in Marennes-Oleron Bay. Aquat. Living Resour. 9, 65-73.

Tran, D., Haberkorn, H., Soudant, P., Ciret, P., Massabuau, J.C., 2010. Behavioral responses of Crassostrea gigas exposed to the harmful algae Alexandrium minutum. Aquaculture 298, 263-267. 
Ref : Influence of Crassostrea gigas (Thunberg) sexual maturation stage and ploidy on uptake of paralytic phycotoxins, Guéguen et al., 2011

\section{FIGURES}
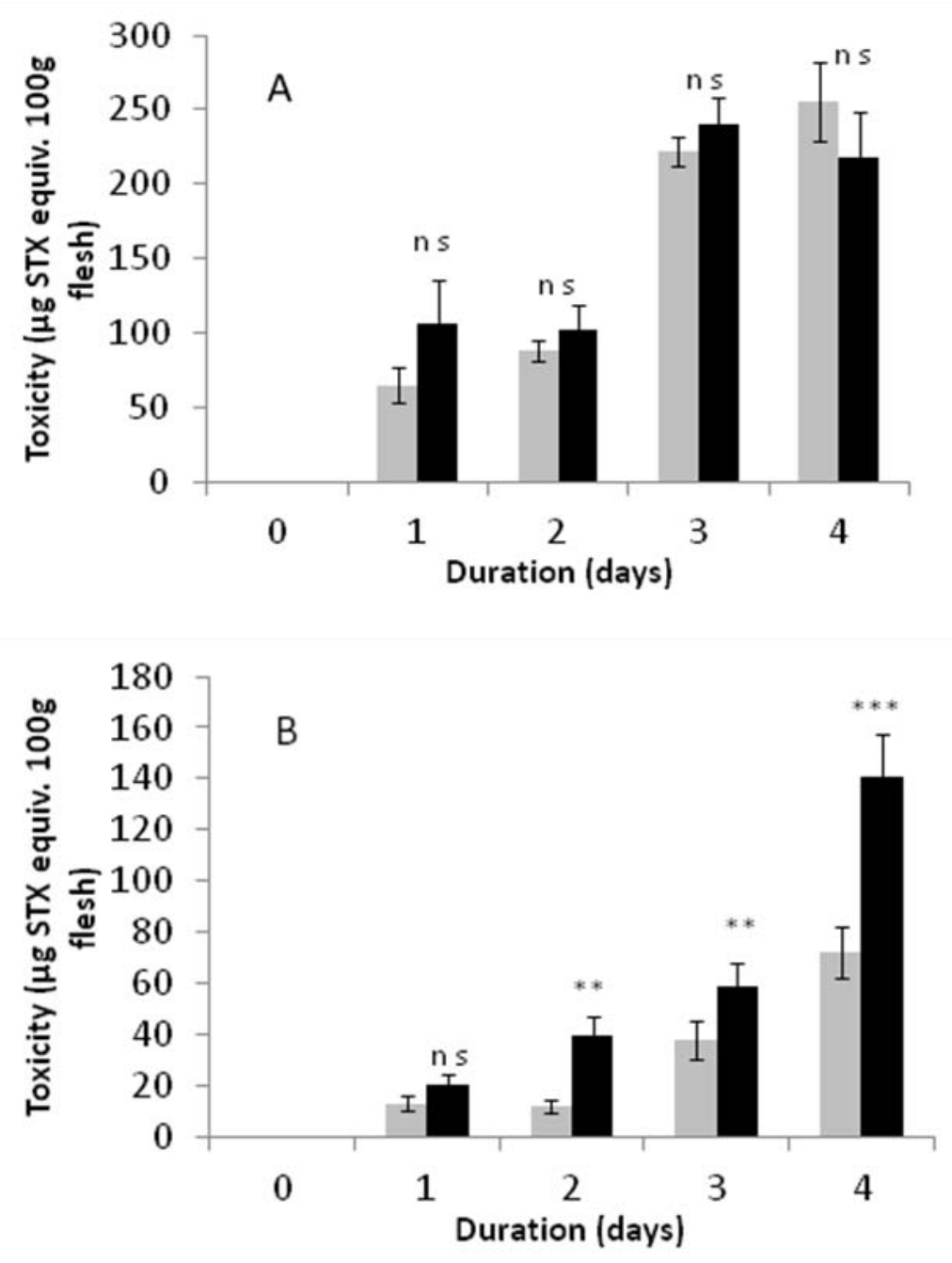

Figure 1: Toxin content of diploid (grey) and triploid (black) oysters over 4 days of contamination by Alexandrium minutum in November (A), at sexual resting stage for diploid oysters, and in June (B), at the peak of sexual maturation for diploid oysters. Mean \pm s.d.; ns: not significant, significant differences labelled ${ }^{* *}: p<0.05$ or ${ }^{* * *}: p<0.01$ 

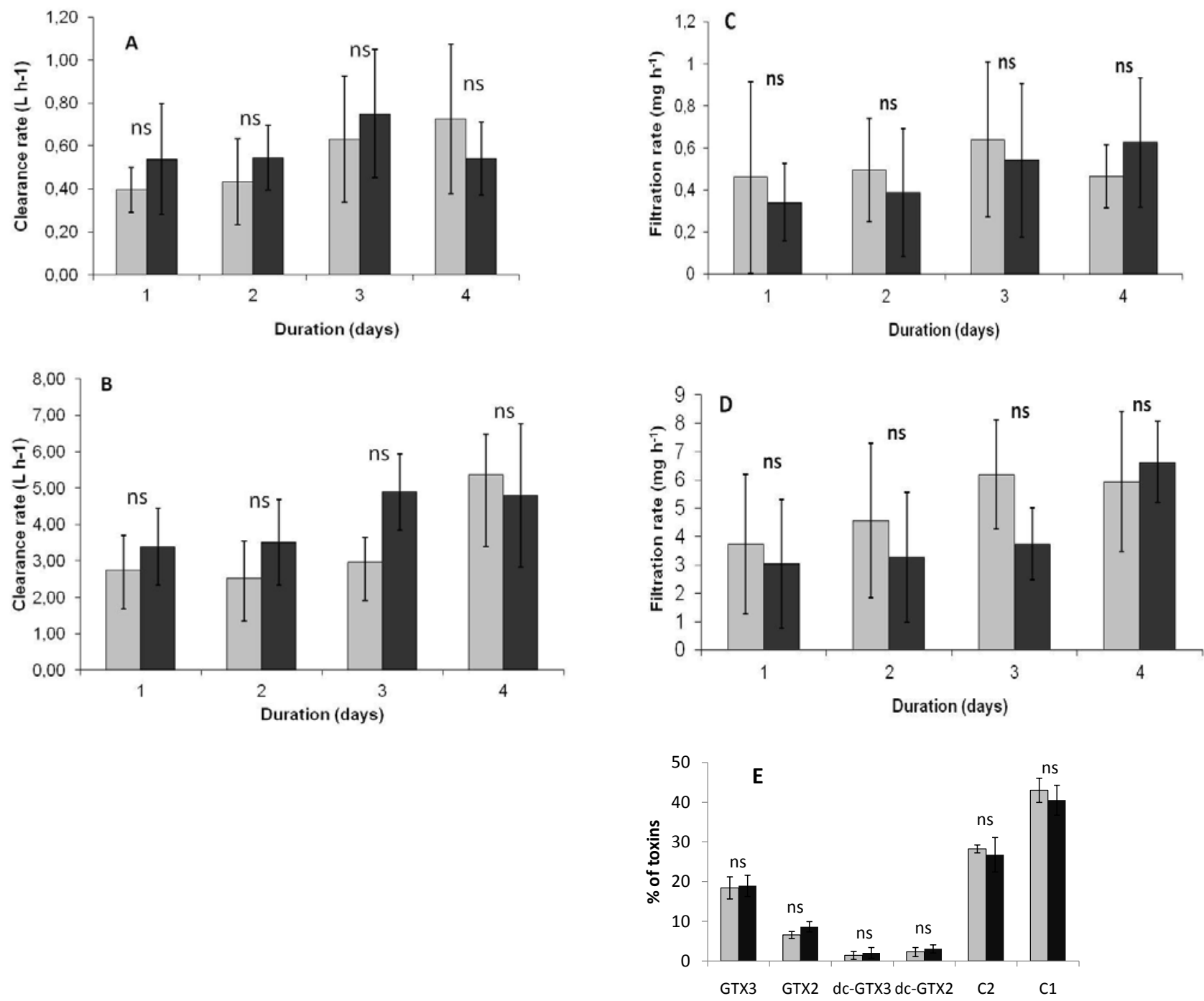

Fig 2 : Evolution of clearance rate ( $A$ and $B)$ and filtration rate $(C$ and $D)$ over 4 days contamination of diploid (grey) and triploid (black) oysters by Alexandrium minutum. In $\mathrm{A}$ and $C$, the diploid oysters were at resting stage; in $B$ and $D$, they were at the end of sexual maturation. $E$ shows the toxin profile for day 4 of the experiment done at the peak of diploid sexual maturity. Means \pm s.d.; ns: not significant. GTX: gonyautoxins, dc-: decarbamoyls, C: C toxins 